\title{
Analysis of Quinolone Resistance Determinants in Escherichia coli Isolated from Clinical Specimens and Livestock Feces
}

\author{
Ji Youn Sung
}

Department of Biomedical Laboratory Science, Far East University, Eumseong, Korea

\section{임상검체와 가축으로부터 분리된 대장균을 대상으로 Quinolone계 항균제 내성인자 분석}

\author{
성지연 \\ 극동대학교 임상병리학과
}

\begin{abstract}
The inappropriate and widespread use of quinolones in humans and animals may cause accelerated emergence and spread of antimicrobial-resistant determinants. In this study, we investigated quinolone resistance mechanisms in a total of 65 nalidixic acid-resistant $E$. coli i isolated from swine rectal swabs $(\mathrm{N}=40)$ and clinical specimens $(\mathrm{N}=25)$. Antimicrobial susceptibilities were determined by the disk diffusion method. PCR and DNA sequencing were performed for investigations of genes and mutations associated with quinolone resistance. In our study, 62 of 65 nalidixic acid-resistant E. coli harbored mutations in gyrA, parC, and/or parE genes; of the 65 isolates, 62 (95.4\%) had mutations in the gyrA gene, $35(53.8 \%)$ had mutations in the parC gene, $7(10.8 \%)$ had mutations in the parE gene. The 35 isolates harbored mutations in two genes, gyrA and parC. Plasmidmediated quinolone resistance (PMQR) determinants were investigated in the 65 isolates. Thirteen of 65 nalidixic acid-resistant E. coli contained the qnrS gene and 10 of those isolates had mutations in the gyrA, parC, and/or parE genes. We confirmed that an important mechanism of quinolone resistance in $E$. coli isolated from human and swine involves chromosomal mutations in the $g y r A$, parC, and/or parE genes with increasing use of quinolone for treatment or additives.
\end{abstract}

Key words: E. coli, gyrA, parC, Plasmid-mediated quinolone resistance

This is an Open Access article distributed under the terms of the Creative Commons Attribution Non-Commercial License (http://creativecommons.org/licenses/by-nc/4.0) which permits unrestricted non-commercial use, distribution, and reproduction in any medium, provided the original work is properly cited.

Copyright @ 2018 The Korean Society for Clinical Laboratory Science. All rights reserved.
Corresponding author: Ji Youn Sung Department of Biomedical Laboratory Science, Far East University, 76-32 Daehak-gil, Gamgok-myeon, Eumseong 27601, Korea Tel: 82-43-879-3668

Fax: 82-43-880-3876

E-mail: azaza72@naver.com

Received: September 28, 2018

Revised $1^{\text {st. }}$ October 18, 2018

Revised $2^{\text {nd: }}$ October 24,2018 Accepted: October 24, 2018

\section{서 론}

Quinolone계열의 항균제는 의료관련 또는 다양한 지역사회 감염병을 일으키는 세균에 대해 효과적인 광범위항균제로 오랫 동안 사용되어 왔으며 동물의 질병치료 및 예방목적으로 축산 분야에서도 널리 사용되고 있는 항균제 중 하나다[1, 2]. 그러나
최근 이 항균제에 내성을 나타내는 장내세균들이 급격하게 증 가하고 있는 것으로 보고되고 있다. 내성을 획득한 장내세균들 은 직접적인 접촉이나 직업적 노출(도축업자) 또는 축산물을 통 해 사람에게 감염될 수 있으며, 이때 내성유전자를 사람의 장내 세균으로 전이시키기도 한다. 내성 세균의 출현 및 확산은 항균 제 사용량과 밀접한 관련이 있는데 국내의 경우 과도한 항균제 
처방으로 인해 항균제의 사용량이 지속적으로 증가되어왔다[3, 4]. 항균제 사용량 증가에 따른 내성 세균의 증가 및 확산은 감염 병 환자를 항균제 선택 압력에 놓이게 하기도 하고 치료의 실패 를 야기하기도 한다[5].

Quinolone계열 항균제는 세균의 DNA 복제에 꼭 필요한 type II topoisomerase 효소인 DNA gyrase와 DNA topoisomerase IV의 기능을 억제함으로써 항균작용을 한다. 이 두 효소는 각각 두 종류의 소단위(subunit)로 구성되는데 DNA gyrase는 GyrA 및 GyrB로 그리고 DNA topoisomerase IV는 ParC 및 ParE로 이루어져있으며 GyrA는 ParC와 유사한 구조를, 그리고 $\mathrm{GyrB}$ 는 ParE와유사한 구조를 갖는다. Quinolone 계열 항균제는 DNA topoisomerase IV보다는 DNA gyrase와 결합했을 때 DNA 복제를 더 빠르게 억제하는 특징이 있다. 일반 적으로 임상에서 사용하는 quinolone계열 항균제는 그람음성 세균의 경우에는 DNA gyrase에 더 효과적이며 그람양성세균 의 경우에는 DNA topoisomerase IV에 더 효과적이라고 보고 되고 있다[6]. 한편 DNA gyrases ( $g_{y} r A$ 및 $g y r B$ )와 topoisomerase IV (parC 및 parE) 효소를 암호화하는 유전자는 quinolone resistance determining regions (QRDRs)라고 불 리우는 영역을 포함하는데 $\mathrm{QRDRs}$ 에 존재하는 염기들에 돌연 변이가 생겨 아미노산이 치환될 경우 세균들은 세균은 quinolone계열 항균제에 내성을 나타내게 된다. 특히 두 효소 에 치환된 아미노산의 수가 많을수록 quinolone계열의 항균제 에 고도내성을 보인다고 한다[6].

장내세균과에 속하는 세균들은 세포의 염색체 DNA 돌연변 이에 의해 quinolone계열의 항균제에 내성을 나타내기도 하지 만 quinolone 내성유전자를 포함하고 있는 plasmid를 획득함 으로써 내성을 나타내기도 한다[6-9]. Plasmid를 통한 quinolone 내성유전자의 획득은 장내세균에서 지속적으로 보 고되어 왔는데 이러한 plasmid-mediated quinolone resistance (PMQR) determinants는 같은 균종 뿐만 아니라 다른 균종에 도 수평 확산될 수 있어 더욱 큰 문제가 되고 있다. 대표적인 PMQR determinants로는 Qnr, AAC(6')-Ib-cr, QepA, OqxAB 등이 있다. Onr은 type II topoisomerase 효소에 quinolone 항균제가 결합하는 것을 방해하여 항균제의 항균 능 력을 저하시킨다[7]. AAC(6')-Ib-cr은 변형된 aminoglycoside acetyltransferase로 항균제의 piperazinyl amine을 acetylation 시켜서 ciprofloxacin 및 norfloxacin의 항균력을 감소시킨다 [8]. QepA와OqxAB는 quinolone 유출펌프단백으로 quinolone 항균제를 세균세포 바깥으로 유출시켜 항균력을 감소시킨다[6, 9].

최근까지 quinolone 계열 항균제에 대한 내성인자 분석은
많이 보고되어 왔으나 주로 사람에서 분리된 세균을 대상으로 이루어진 연구였으며 가축으로부터 분리된 세균을 대상으로는 한 연구는 드문 편이다. 다양한 경로로 항균제 내성 세균이 증가 하고 있고 가축과 사람에게 사용되는 항균제 량이 증가하면서 가축유래 항균제 내성 세균이 가축으로부터 직접 또는 축산물 유통과정에서 사람에게 전달될 수 있어 문제가 될 수 있음에도 사람과 가축으로부터 분리된 세균을 대상으로 내성인자분석을 비교·분석한 연구는 매우 드물다. 본 연구에서는 사람과 가축으 로부터 대장균을 분리하여 quinolone 계열 항균제에 대한 내성 인자분석을 비교 - 분석하고자 하였다. 대장균은 장내세균과에 속하는 세균으로 가장 빈번하게 사람이나 동물의 위장관 검체 로부터 분리되는데 의료관련 감염, 뿐만 아니라 지역사회 감염 의 주된 원인균으로 알려져 있다. 특히 종합병원에 의뢰된 임상 검체로부터 분리된 대장균이라 하더라도 입원하기 48시간전에 지역사회에서 획득한 경우가 다수 있어 지역사회 감염 빈도가 매우 높을 것으로 여겨지고 있다[10]. 따라서 사람과 가축의 항 균제 내성 양상을 모니터링하기에 가장 적합한 세균 중 하나라 판단된 대장균을 대상으로 $\mathrm{QRDRs}$ 의 염색체 돌연변이와 $\mathrm{PMQR}$ determinants를 분석하였다. 본 연구는 사람과 가축에 모두 중요한 항균제인 quinolones 계열 항균제에 내성을 갖는 세균의 확산을 방지하기 위한 기초자료가 될 것으로 사료된다.

\section{재료 및 방법}

\section{1. 균주의 수집 및 균종 동정}

본 연구를 위한 대장균은 2017년 5월부터 2017년 9월까지 충청지역에 위치한 양돈농가에서 사육된 돼지 $(\mathrm{N}=113)$ 와 동일 지역에 위치한 일개의 대학병원에 의뢰된 임상검체로부터 (N=54) 분리되었다. 돼지로부터 대장균을 분리하기 위해 멸균 된 면봉을 돼지의 직장에 삽입한 후 면봉을 돌려가며 직장내의 변을 채취한 후 Stuart 수송배지(Oxoid, Basingstoke, UK)에 면봉을 넣어 검사실로 운반하였다. 항균제 내성에 상관없이 분 리된 순서대로 균주를 수집하였으며 임상검체로부터 분리된 균 주의 경우 동일대상에서 반복하여 분리된 균주는 수집대상에서 제외하였다. 각각의 검체로부터 분리배양된 균주를 Vitek $2^{\circledR}$ automated instrument ID system (bioMérieux, Marcy l'Etoile, France)을 이용하여 생화학적 방법으로 동정하였다.

\section{2. 항균제 감수성 시험}

분리된 대장균을 대상으로 Mueller-Hinton 한천배지(Difco, Cockeysville, MD, USA)를 사용하여 amikacin, ampicillin, 
cefotaxime, ciprofloxacin, gentamicin, levofloxacin, nalidixic acid, streptomycin, trimethoprim 및 tobramycin (Oxoid)에 대한 감수성을 Clinical and Laboratory Standards Institute (CLSI) 지침에 따라 디스크 확산법으로 확인하였다 [11]. 정도관리를 위해 Escherichia coli ATCC 25922와 Pseudomonas aeruginosa ATCC 27853을 동시에 시험하여 허용범위내에 있는지 확인하였다.

\section{Quinolone 내성인자 검출}

항균제 감수성 검사에서 nalidixic acid에 내성을 나타낸 대 장균을 대상으로 quinolone 내성인자를 조사하였다. QRDRs 에 위치한 $g y r A, \operatorname{gyr} B, \operatorname{par} C$ 및 $\operatorname{par} E$ 유전자의 돌연변이를 확인 하고 PMQR determinants인 $q n r A, q n r B$, qnrS, aac(6)-Ib-cr, $\triangle q \times A$ 및 $q e p A$ 유전자를 검출하기 위해 기존의 primer (Table 1)를 사용하여 중합효소연쇄반응을 수행하였다[7, 8, 12-14]. 먼저 대상 균주를 brain heart infusion broth (Difco)에 접종하 여 $37^{\circ} \mathrm{C}$ 에서 18 시간 배양한 후 DNA purification kit (Bioneer, Daejeon, Korea)을 사용하여 주형으로 사용할 DNA를 추출하 였다. AccuPower PCR PreMix (Bioneer)에 DNA 추출액 (3 $\mu \mathrm{L})$, primer 각 $10 \mathrm{pmol}$ 및 증류수를 혼합하여 총 부피 $25 \mu \mathrm{L}$ 의 반응용액을 만들었다. GenePro Thermal Cycler B48D (Hangzhou Bioer Technology Corp. Ltd, China)에서 $95^{\circ} \mathrm{C}$
에서 5 분간 반응시킨 후, $95^{\circ} \mathrm{C}$ 에서 30 초, $53^{\circ} \mathrm{C}$ 에서 30 초, $72^{\circ} \mathrm{C}$ 에서 30 초씩 30 회 증폭 반응시키고, $72^{\circ} \mathrm{C}$ 에서 5 분간 연 장 반응시켰다. 각각의 증폭산물을 PCR purification kit (Bioneer)을 이용하여 분리 한 후, BigDye Terminator Cycle Sequencing Kit (PE Applied Biosystems, Foster City, CA, USA)와 ABI PRISM 3730xl DNA analyzer (PE Applied Biosystems)을 이용하여 염기서열을 분석하였다. 결정된 각각 의 염기서열을 NCBI에서 제공하는 BLAST 프로그램을 이용하 여 각각의 참조 대장균 유전자와 비교 분석하였다.

\section{결 과}

\section{Nalidixic acid 내성 대장균의 분리}

수집기간동안 대장균 총 113 균주가 돼지의 직장면봉검체 (Swine rectal swabs, SRSs)로부터 분리되었으며 이 중 nalidixic acid에 내성을 보인 균주는 40 균주로 약 $35.7 \%$ 의 내 성율을 보였다. 같은 기간 동안 임상검체(Clinical specimens, $\mathrm{CSs}$ )로부터는 총 54 균주의 대장균이 분리되었는데 이중 25 균 주가 nalidixic acid에 내성을 보여 $46.3 \%$ 의 내성율을 나타냈다.

\section{2. 항균제 내성 양상}

수집기간동안 SRSs와 CSs로부터 총 65균주의 nalidixic

Table 1. Oligonucleotides used in present study for detection of quinolone resistance determinants

\begin{tabular}{|c|c|c|c|}
\hline Primer & Sequence $\left(5^{\prime}-3^{\prime}\right)$ & Gene & References \\
\hline \multicolumn{4}{|c|}{ QRDRs PCR detection } \\
\hline gyrA-F & TCTGGATTATGCGATGTCGGTCAT & gyrA & {$[12]$} \\
\hline gyrA-R & TCAGCCCTTCAATGCTGATGTCT & & \\
\hline gyrB-F & GCTGAGCGAATACCTGCTGG & gyrB & [12] \\
\hline gyr $B-R$ & TCGGTCATGATGATGATGCTGTGAT & & \\
\hline $\operatorname{parC}-\mathrm{F}$ & ACTACTCCATGTACGTCATCATGGAC & parC & [12] \\
\hline $\operatorname{parc}-\mathrm{R}$ & CGCCACTTCGCGCAGGTTAT & & \\
\hline parE-F & GCGGAAGATATCTGGGATCGCT & parE & [12] \\
\hline parE-R & CTGGCTCAGATCGTCGCTGT & & \\
\hline \multicolumn{4}{|c|}{ PMQR gene detection } \\
\hline qnrA-F & AGAGGATTTCTCACGCCAGG & qnrA & [7] \\
\hline qnrA-R & TGCCAGGCACAGATCTTGAC & & \\
\hline$q n r B-F$ & GGMATHGAAATTCGCCACTG & $q n r B$ & [7] \\
\hline$q n r B-R$ & TTTGCYGYYCGCCAGTCGAA & & \\
\hline qnrS-F & GCAAGTTCATTGAACAGGGT & qnrs & [7] \\
\hline qnrS-R & TCTAAACCGTCGAGTTCGGCG & & \\
\hline $\operatorname{aac}(6)-I b-F$ & TTGCGATGCTCTATGAGTGGCTA & $\operatorname{aac}(6)-1 b-c r$ & [8] \\
\hline $\operatorname{aac}(6)-1 b-R$ & CTCGAATGCCTGGCGTGTTT & & \\
\hline$q e p A-\mathrm{F}$ & CCAGCTCGGCAACTTGATAC & qepA & [13] \\
\hline qepA-R & ATGCTCGCCTTCCAGAAAA & & \\
\hline$O q \times A-\mathrm{F}$ & CTCGGCGCGATGATGCT & $o q \times A$ & [14] \\
\hline oq $\times A-\mathrm{R}$ & CCACTCTTCACGGGAGACGA & & \\
\hline
\end{tabular}

Abbreviations: $F$, forward (sense) primer; $R$, reverse (antisense) primer; $M, A / C ; H, A / T / C ; Y, C / T$. 
acid 내성 대장균이 분리되었는데 SRSs로부터 분리된 균주가 40균주, 그리고 CSs로부터 분리된 균주가 25균주였다. 이 균주 들을 대상으로 항균제 감수성 시험을 한 결과 CSs로부터 분리된 균주들이 SRSs로부터 분리된 균주들에 비해 시험항균제들에 대해 모두 높은 내성률을 보였다(Table 2). 특히 cefotaxime의 경우에는 SRSs로부터 분리된 균주들은 모두 감수성을 보인 반 면 CSs로부터 분리된 균주들은 모두 내성을 나타냈다. 한편 SRSs로부터 분리된 균주들의 경우 nalidixic acid (100\%), streptomycin (70.0\%) 및 ampicillin (62.5\%)를 제외한 시험항
균제들에 대해서는 $50 \%$ 미만의 내성률을 나타냈다.

\section{Quinolone 내성인자 검출 및 분석}

\section{1) QRDRs에 위치한 유전자의 돌연변이 확인}

돼지와 사람으로부터 분리된 nalidixic acid 내성 대장균을 대상으로 $g_{y r} A, g_{r} B, \operatorname{par} C$ 및 $\operatorname{par} E$ 유전자 돌연변이가 있는지 를 조사한 결과 $g y r A, p a r C$ 및 $p a r E$ 유전자에서 다양한 점 돌연 변이가 확인되었다(Figure 1). 본 연구에서 확인된 $g y r A$ 유전자 돌연변이는 염기의 치환에 의해 83번째 아미노산(serine, S)이

Table 2. Antimicrobial susceptibilities of $E$. coli strains isolated from swine rectal swabs and clinical specimens

\begin{tabular}{|c|c|c|c|c|c|c|}
\hline \multirow{2}{*}{ Antimicrobial agent } & \multicolumn{3}{|c|}{ No. (\%) of SRSs } & \multicolumn{3}{|c|}{ No. (\%) of CSs } \\
\hline & $\mathrm{S}$ & 1 & $\mathrm{R}$ & $\mathrm{S}$ & I & $\mathrm{R}$ \\
\hline Amikacin & $40(100.0)$ & $0(0.0)$ & $0(0.0)$ & $5(20.0)$ & $19(76.0)$ & $1(4.0)$ \\
\hline Gentamicin & $24(60.0)$ & $0(0.0)$ & $16(40.0)$ & $13(52.0)$ & $1(40.0)$ & $11(44.0)$ \\
\hline Tobramycin & $27(67.5)$ & $4(10.0)$ & $9(22.5)$ & $12(48.0)$ & $3(12.0)$ & $10(40.0)$ \\
\hline Streptomycin & $8(20.0)$ & $4(10.0)$ & $28(70.0)$ & $0(0.0)$ & $2(8.0)$ & $23(92.0)$ \\
\hline Ampicillin & $14(35.0)$ & $1(2.5)$ & $25(62.5)$ & $0(0.0)$ & $0(0.0)$ & $25(100.0)$ \\
\hline Cefotaxime & $40(100.0)$ & $0(0.0)$ & $0(0.0)$ & $0(0.0)$ & $0(0.0)$ & $25(100.0)$ \\
\hline Nalidixic acid & $0(0.0)$ & $0(0.0)$ & $40(100.0)$ & $0(0.0)$ & $0(0.0)$ & $25(100.0)$ \\
\hline Levofloxacin & $23(57.5)$ & $5(12.5)$ & $12(30.0)$ & $5(20.0)$ & $2(8.0)$ & $18(72.0)$ \\
\hline Ciprofloxacin & $24(60.0)$ & $5(12.5)$ & $11(27.5)$ & $3(12.0)$ & $3(12.0)$ & $19(76.0)$ \\
\hline Trimethoprim & $22(55.0)$ & $4(10.0)$ & $14(35.0)$ & $10(40.0)$ & $0(0.0)$ & $15(60.0)$ \\
\hline
\end{tabular}

Abbreviations: SRSs, swine rectal swabs; CSs, clinical specimens; S, susceptible; I, intermediate resistant; R, resistant.
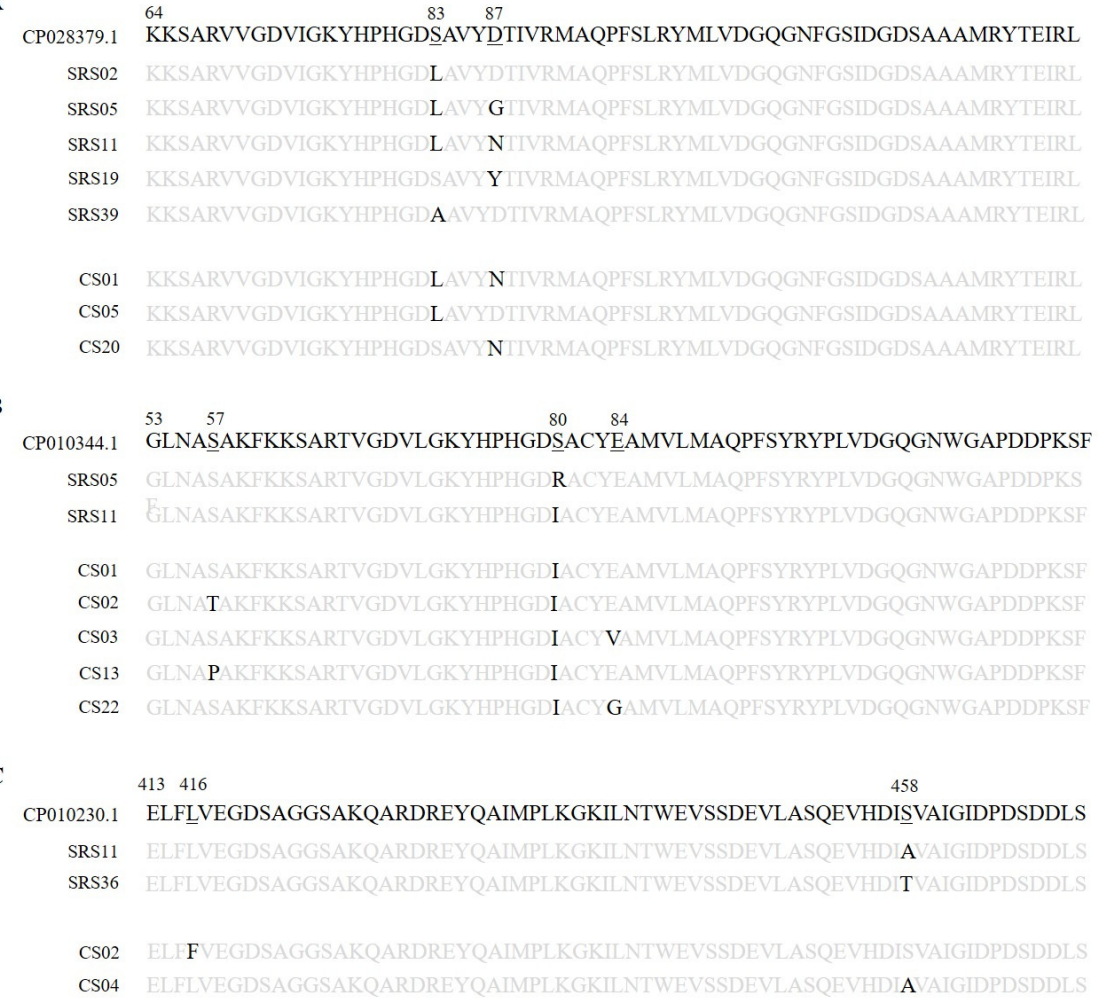

Figure 1. Amino acid variations of GyrA (A), ParC (B), and ParE (C) detected in $E$. coli isolates involved in this study and reference amino acid sequence with accession number CPO 28379.1, CP010344.1 and CP010230.1, respectively. SRSs and CSs mean swine rectal swabs and clinical specimens, respectively. 
Table 3. Quinolone resistance determinants of $E$. coli isolates showing resistant to nalidixic acid

\begin{tabular}{|c|c|c|c|c|c|c|}
\hline \multirow{2}{*}{ Isolate } & \multirow{2}{*}{ Specimens } & \multirow{2}{*}{ Phenotype* $^{\star}$} & \multicolumn{3}{|c|}{ Mutations in QRDRs } & \multirow{2}{*}{$\mathrm{PMQR}^{\dagger}$ genes } \\
\hline & & & GyrA & ParC & ParE & \\
\hline SRS1 & Swine feces & NA & Wild type & Wild type & Wild type & qnrs \\
\hline SRS2 & Swine feces & NA & S83L & Wild type & Wild type & \\
\hline SRS3 & Swine feces & NA & S83L & Wild type & Wild type & \\
\hline SRS4 & Swine feces & NA & S83L & Wild type & Wild type & \\
\hline SRS5 & Swine feces & NA & S83L, D87G & S80R & Wild type & \\
\hline SRS6 & Swine feces & NA & S83L, D87G & S80R & Wild type & \\
\hline SRS7 & Swine feces & NA & S83L, D87G & S80R & Wild type & \\
\hline SRS8 & Swine feces & NA & S83L & Wild type & Wild type & \\
\hline SRS9 & Swine feces & NA & S83L & Wild type & Wild type & \\
\hline SRS10 & Swine feces & NA & S83L & Wild type & Wild type & \\
\hline SRS11 & Swine feces & NA, LEV, CIP & S83L, D87N & S80I & S458A & \\
\hline SRS12 & Swine feces & NA, LEV, CIP & S83L, D87N & S80R & Wild type & \\
\hline SRS13 & Swine feces & NA, LEV, CIP & S83L, D87G & S80R & Wild type & \\
\hline SRS14 & Swine feces & NA & S83L & Wild type & Wild type & \\
\hline SRS15 & Swine feces & NA, LEV & S83L & Wild type & Wild type & qnrs \\
\hline SRS16 & Swine feces & NA, LEV, CIP & S83L, D87N & S80I & Wild type & \\
\hline SRS17 & Swine feces & NA & S83L & Wild type & Wild type & \\
\hline SRS18 & Swine feces & NA & S83L & Wild type & Wild type & \\
\hline SRS19 & Swine feces & NA & D87Y & Wild type & Wild type & \\
\hline SRS20 & Swine feces & NA & Wild type & Wild type & Wild type & qnrs \\
\hline SRS21 & Swine feces & NA, LEV, CIP & S83L, D87N & S80R & Wild type & \\
\hline SRS22 & Swine feces & NA & S83L & Wild type & Wild type & qnrs \\
\hline SRS23 & Swine feces & NA, LEV, CIP & S83L, D87N & S80I & Wild type & \\
\hline SRS24 & Swine feces & NA & S83L & Wild type & Wild type & \\
\hline SRS25 & Swine feces & NA, LEV, CIP & S83L, D87N & S80I & Wild type & \\
\hline SRS26 & Swine feces & NA & S83L, D87G & S80R & Wild type & \\
\hline SRS27 & Swine feces & NA & S83L & Wild type & Wild type & \\
\hline SRS28 & Swine feces & NA, LEV, CIP & S83L, D87G & S80R & Wild type & \\
\hline SRS29 & Swine feces & NA & S83L & Wild type & Wild type & \\
\hline SRS30 & Swine feces & NA & S83L & Wild type & Wild type & \\
\hline SRS31 & Swine feces & NA & S83L & Wild type & Wild type & \\
\hline SRS32 & Swine feces & NA & S83L & Wild type & Wild type & \\
\hline SRS33 & Swine feces & NA & S83L & Wild type & Wild type & \\
\hline SRS34 & Swine feces & NA & S83L & Wild type & Wild type & \\
\hline SRS35 & Swine feces & NA & S83L, D87G & S80R & Wild type & \\
\hline SRS36 & Swine feces & NA, LEV, CIP & S83L, D87N & S80I & S458T & \\
\hline SRS37 & Swine feces & NA, LEV, CIP & S83L, D87N & S80R & Wild type & \\
\hline SRS38 & Swine feces & NA & S83L & S80R & Wild type & \\
\hline SRS39 & Swine feces & NA & S83A & Wild type & Wild type & \\
\hline SRS40 & Swine feces & NA, LEV, CIP & S83L, D87N & S80I & S458A & \\
\hline CS1 & Urine & NA, LEV, CIP & S83L, D87N & S80I & Wild type & qnrs \\
\hline CS2 & Urine & NA, LEV, CIP & S83L, D87N & S57T, S80I & L416F & qnrs \\
\hline CS3 & Urine & NA, LEV, CIP & S83L, D87N & S80I, E84V & Wild type & qnrs \\
\hline CS4 & Body Fluid & NA, LEV, CIP & S83L, D87N & Wild type & S458A & \\
\hline CS5 & Urine & NA & S83L & Wild type & Wild type & qnrs \\
\hline CS6 & Urine & NA, LEV, CIP & S83L, D87N & S801 & Wild type & qnrs \\
\hline CS7 & Sputum & NA, LEV, CIP & S83L, D87N & S80I, E84V & Wild type & \\
\hline CS8 & Blood & NA, LEV, CIP & S83L, D87N & S80I & Wild type & \\
\hline CS9 & Urine & NA, LEV, CIP & S83L, D87N & S80I, E84V & Wild type & qnrs \\
\hline CS10 & Blood & NA, CIP & Wild type & Wild type & Wild type & qnrs \\
\hline CS11 & Body fluid & NA, LEV, CIP & S83L, D87N & S80I, E84V & Wild type & qnrs \\
\hline CS12 & Blood & NA, LEV, CIP & S83L, D87N & S80I, E84V & Wild type & \\
\hline CS13 & Urine & NA & S83L, D87N & S57P, S80I & Wild type & \\
\hline
\end{tabular}


Table 3. Continued

\begin{tabular}{cccccc}
\hline \multirow{2}{*}{ Isolate } & Specimens & Phenotype* & \multicolumn{3}{c}{ Mutations in QRDRs } \\
\cline { 4 - 5 } & & & GyrA & ParC & ParE \\
\hline CS14 & Urine & NA & S83L & Wild type & S458A \\
CS15 & Urine & NA, LEV, CIP & S83L, D87N & S80I, E84V & Wild type \\
CS16 & Urine & NA, LEV, CIP & S83L, D87N & S80I & Wild type \\
CS17 & Urine & NA, LEV, CIP & S83L, D87N & S80I, E84V & Wild type \\
CS18 & Urine & NA & S83L & Wild type & Wild type \\
CS19 & Urine & NA, LEV, CIP & S83L, D87N & S80I, E84V & Wild type \\
CS20 & Urine & NA & D87N & Wild type & Wild type \\
CS21 & Blood & NA, LEV, CIP & S83L, D87N & S80I & Wild type \\
CS22 & Urine & NA, LEV, CIP & S83L, D87N & S80I, E84G & Wild type \\
CS23 & Urine & NA, LEV, CIP & S83L, D87N & S80I & Wild type \\
CS24 & Urine & NA & S83L & Wild type & S458A \\
CS25 & Pus & NA, LEV, CIP & S83L, D87N & S80I, E84G & Wild type \\
\hline
\end{tabular}

Abbreviations: SRSs, swine rectal swabs; CSs, clinical specimens; AK, amikacin; CN, gentamicin; TOB, tobramycin; S, streptomycin; AMP, ampicillin; CTX, cefotaxime; NA, nalidixic acid; LEV, levofloxacin; CIP, ciprofloxacin; W, trimethoprim; QRDR, quinolone resistance-determining regions.

${ }^{*}$ Antimicrobial resistant phenotypes about quinolones: nalidixic acid, levofloxacin and ciprofloxacin, ${ }^{\dagger}$ Plasmid-mediated quinolone resistance (PMQR) genes: qnr, aac(6')- $16-c r$, qepA and oqxA.

alanine (A) 또는 leucine (L)으로 바뀌거나(S83A, S83L) 87번 째 아미노산(aspartic acid, D)이 glycine (G), asparagine (N) 또는 tyrosine (Y)으로 치환된 돌연변이(D87G, D87N, D87Y) 였다. $\operatorname{par} C$ 유전자 돌연변이는 $g y r A$ 유전자 돌연변이보다 더 다양하였으며 57번째 아미노산(S), 80번째 아미노산(S) 그리고 84번째 아미노산(glutamic acid, E)에서 돌연변이들이 확인되 었다. 57번째 S가 proline (P) 또는 threonine (T)으로 치환된 돌연변이(S57P, S57T), 80번째 S가 arginine (R) 또는 L로 치환 된 돌연변이(S80R, S80L), 그리고 84번째 E가 G 또는 valine $(\mathrm{V})$ 로 치환된 돌연변이(E84G, $\mathrm{E} 84 \mathrm{~V})$ 들이 본 연구에서 확인되 었다. parE 유전자분석을 통해 확인된 돌연변이는 416번째 아 미노산(L)이 phenylalanine (F)로 치환된 돌연변이(L416F)와 458번째 아미노산(S)이 A 또는 T로 치환된 돌연변이(S458A, S458T)들이었다. 이번 연구에서는 quinolone 항균제에 내성 을 나타내는 것으로 알려져 있는 돌연변이를 $g y r B$ 유전자에 가 지고 있는 대장균은 없는 것으로 나타났다.

한편, 본 연구에서는 조사된 대장균 총 65 균주 중 3 균주를 제 외한 62개의 균주가 $g y r A, \operatorname{par} C$ 및/또는 parE 유전자에 돌연변 이를 포함하고 있었는데 62균주(95.4\%)가 gyrA 유전자에 돌연 변이를 포함하고 있었고, 35균주(53.8\%)가 parC 유전자에 돌 연변이를 갖고 있었으며, 7균주(10.8\%)가 parE 유전자에 돌연 변이를 가지고 있는 것으로 나타났다(Table 3). gyrA 유전자에 돌연변이를 포함하고 있는 62균주 중 35균주가 $\operatorname{parC}$ 유전자에 동시에 돌연변이를 가지고 있었는데 이들 중 28 균주가 본 연구 에서조사된 quinolone 계열 항균제(nalidixic acid, levofloxacin, ciprofloxacin)에 모두 내성을 보였다. 덧붙여, 62균주 중 38균 주는 두개 이상의 유전자에 동시에 돌연변이를 가지고 있음이 확인되었는데 사람에게서 유래한 대장균은 84.0\% (21/25)가 두개 이상의 유전자에 돌연변이를 가지고 있었던 반면 돼지에 게서 유래한 대장균은 42.5\% (17/40)가 두개 이상의 유전자에 돌연변이를 포함하고 있는 것으로 나타났다.

\section{2) $P M Q R$ determinants 검출}

본 연구에서는 65 균주의 nalidixic acid 내성 대장균을 대상 으로 PMQR determinants인 aac( $\left.6^{\prime}\right)-I b-c r, o q x A, q e p A$, $q n r A, q n r B$ 및 $q n r S$ 유전자의 빈도를 조사하기 위해 중합효소 연쇄반응을 시행한 결과 $q n r S$ 유전자를 검출하기 위한 반응액 을 제외하고는 양성반응이 나타나지 않았다. 염기서열분석을 통해 $q n r S$ 유전자임이 확인된 균주는 총 13균주였는데, 이들 중 $\mathrm{QRDRs}$ 에 돌연변이를 포함하지 않는 균주는 SRS1, SRS20과 $\mathrm{CS} 10$ 으로 나타났다. 그리고 $q n r S$ 유전자를 포함하는 총 13균 주 중 9균주가 $\mathrm{CSs}$ 로부터 분리된 대장균이었고 4 균주만 SRSs 로부터 분리된 대장균이었다.

\section{고 찰}

축산농가에서도 많이 사용하고 있고 임상에서도 환자의 치 료를 위해 빈번하게 사용되고 있는 quinolone 계열 항균제에 내성을 나타내는 세균이 증가하고 있어 사람뿐 만 아니라 가축 을 대상으로 quinolone 계열 항균제 내성 기전을 연구하는 것 
은 중요하다. 따라서 본 연구에서는 가축과 사람에서 분리된 대 장균을 대상으로 quinolone 계열 항균제에 대한 내성율과 어떠 한 내성 인자를 포함하여 내성을 나타내는지를 조사하였다.

연구기간 동안 총 65 균주의 nalidixic acid 내성 대장균이 수 집되었고, 이 균주를 대상으로 $\mathrm{QRDRs}$ 에 위치한 유전자의 돌연 변이를 확인하였다. 대장균이 quinolone계열 항균제에 내성을 나타내는 중요한 기전 중 하나가 DNA gyrase 및/또는 DNA topoisomerase IV의 QRDRs에 돌연변이를 가지는 경우인데 특이 이 경우 세균은 quinolone계열 항균제에 고도 내성을 나 타낸다고 한다[15]. 본 연구에서 분리된 nalidixic acid 내성 대 장균은 $g y r B$ 유전자를 제외한 나머지 $g y r A, p a r C$, parE 유전자 에 다양한 점 돌연변이를 포함하고 있었는데 $g y r A$ 유전자에 돌 연변이를 포함하고 있는 균주가 $95.4 \%$ 로 가장 많았고 $\operatorname{parC}$ 유 전자에 돌연변이를 갖고 있는 균주가 $53.8 \%$ 로 그 다음으로 많 았다. 이와 비교해 parE 유전자에 돌연변이를 포함하고 있는 대 장균은 $10.8 \%$ 로 상대적으로 돌연변이 비율이 낮았으며 $g y r B$ 유전자에서는 돌연변이가 검출되지 않았다. 이전의 많은 연구 자들도 quinolone계열 항균제에 내성을 나타내는 세균들이 $\operatorname{gyr} B$ 및 $\operatorname{parE}$ 유전자 보다는 상대적으로 $\operatorname{gyr} A$ 및 $\operatorname{par} C$ 유전자 에 빈번하게 돌연변이를 포함하고 있다고 보고하였다 $[6,16$, 17]. 국내에서 사육된 돼지의 분변에서 분리된 대장균을 대상으 로 한 연구에서도 $g_{y r} B$ 유전자를 제외한 나머지 3개의 유전자 에서만 돌연변이를 확인한 바 있으며, 독일에서 임상검체로부 터 분리된 대장균을 대상으로 한 연구에서도 $g y r B$ 유전자를 뺀 나머지 3 개의 유전자에서 돌연변이를 확인했다고 보고하였다 $[16,17]$.

한편, nalidixic acid 내성 대장균 65균주 중 QRDRs에 2개 이상의 돌연변이를 포함하는 균주의 비율이 CSs로부터 분리된 대장균은 $84.0 \%$ 이었던 반면 SRSs로부터 분리된 대장균은 $42.5 \%$ 인 것으로 나타나 사람에서 유래한 대장균의 돌연변이 비율이 돼지에서 유래된 대장균과 비교해 높은 것으로 확인되 었다. 세균은 $\mathrm{QRDRs}$ 유전자 중 특히 gyrA와 parC 유전자에 동 시에 돌연변이를 가질 경우 quinolone 계열 항균제에 고도 내 성을 갖는다[17]. 본 연구에서 수집된 총 65균주의 nalidixic acid 내성 대장균 중 35 균주가 $g y r A$ 와 $\operatorname{parC}$ 유전자에 동시에 돌연변이를 가지고 있었는데 이들 중 $80 \%$ 에 해당하는 28 균주 가 quinolone 계열 항균제(nalidixic acid, levofloxacin, ciprofloxacin)에 모두 내성을 보였다(Table 3). 게다가 이 균주 들은 돌연변이 개수가 3 개 5개인 것으로 나타나 이전의 보고 와 유사한 결과를 보였다[12]. 본 연구에서 확인된 QRDRs의 돌 연변이는 SRSs로부터 분리된 대장균과 $\mathrm{CSs}$ 로부터 분리된 대장
균간에는 큰 차이가 없는 것으로 나타났다. $g y r A$ 유전자 돌연변 이는 83번과 87번째 아미노산에서 확인되었고, $\operatorname{parC}$ 유전자 돌연변이는 57번, 80 번 및 84번 아미노산에서 확인되었으며, parE 유전자 돌연변이는 146 번과 458 번째 아미노산에서 확인 되었는데(Figure 1) 이 돌연변이들은 이전에 사람과 동물에서 분리된 대장균에서 빈번하게 보고된 돌연변이였다[17-19].

본 연구에서 분리된 nalidixic acid 내성 대장균이 PMQR determinants인 유전자를 포함하고 있는지 조사한 결과 $q n r S$ 유전자만 총 13 균주 $(20 \%)$ 에서 검출되었는데 이 13 균주 중 10 균주는 $\mathrm{QRDRS}$ 에 돌연변이를 포함하고 있었다. QRDRs에 돌 연변이가 없고 qnrS 유전자만 포함하는 3균주 중 2균주는 nalidixic acid에만 내성을 나타냈으며 나머지 한 균주는 nalidixic acid 및 ciprofloxacin에 내성을 나타냈다. 이 결과는 대장균이 qnrS 유전자만 포함할 경우 $\mathrm{QRDRs}$ 에 돌연변이를 포 함하는 경우보다상대적으로 quinolone계열 항균제에 대해 내 성을 나타낼 확률이 낮음을 의미한다. 이전의 많은 연구들 또한 PMQR determinants인 유전자들은 quinolone계열 항균제에 대해 낮은 수준의 내성을 담당한다고 보고한 바 있다[20, 21]. 그러나 $q n r$ 유전자는 다양한 항균제에 내성을 나타낼 수 있는 유전자들을 포함하고 있는 plasmid에 위치해 있는 경우가 많아 $q n r$ 유전자의 존재는 매우 중요한 의미를 갖는다[6]. 본 연구에 서는 총 13 균주(20\%)가 $q n r$ 유전자를 포함하는 것으로 나타났 는데 이전의 fluoroquinolone 내성 장내세균과를 대상으로 한 연구에서도 $19 \%$ 가 $q n r$ 유전자를 포함하고 있는 것으로 보고된 바 있다[9].

사람과 가축에서 quinolone 내성 대장균의 분리 빈도가 지 속적으로 증가하고 있음에도 불구하고 사람과 가축으로부터 분 리된 대장균을 대상으로 quinolone 내성 기전을 조사한 연구는 상대적으로 많지 않았다. 본 연구에서는 사람과 돼지에서 유래 한 대장균을 대상으로 quinolone 내성 인자를 분석하였는데 사 람과 돼지에서 유래한 대장균 모두 quinolone 계열 항균제에 대한 내성은 PMQR determinants인 유전자들의 획득 보다는 QRDRs 특히 $g y r A$ 및 $p a r C$ 유전자에 돌연변이 발생에 의해 나 타남을 확인할 수 있었다. 이는 quinolone 내성유전자가 plasmid등을 통해 수평확산되서 내성을 전파하기보다는 세균 이 quinolone 계열 항균제에 노출된 뒤 염색체의 돌연변이에 의해 내성을 획득하게 됨을 의미한다. Quinolone 항균제에 대 한 내성 세균의 출현 및 확산은 quinolone 계열 항균제 사용량 의 지속적인 증가와 무분별한 사용 때문인 것으로 사료되며 이 를 방지하게 위해서는 지속적으로 항균제 사용량을 줄이고 항 균제 내성 인자를 조사하여 내성 세균의 출현 및 확산 양상을 감 
시해야 할 것이다.

\section{요 약}

퀴놀론 항균제가 사람과 동물에게 부적절하고 광범위하게 사용될 경우 항균제내성인자의 출현 및 확산이 가속화 될 수 있 다. 본 연구에서는 돼지의 직장면봉 검체 $(\mathrm{N}=40)$ 및 임상 검체로 $(\mathrm{N}=25)$ 부터 분리된 총 65 균주의 nalidixic acid 내성 대장균을 대상으로 quinolone 내성 기전을 조사하였다. 항균제 감수성 은 디스크 확산법에 의해 결정되었다. Quinolone 내성과 관련 된 유전자와돌연변이를 조사하기 위해 PCR 및 DNA sequencing 이 수행되었다. 총 65 균주의 nalidixic acid 내성 대장균 중 62 균주가 gyrA, parC, parE 유전자에 돌연변이를 포함하고 있었 는데, $g y r A$ 유전자에 돌연변이를 포함하고 있는 균주는 62균주 (95.4\%)였고, 35균주(53.8\%)가 parC 유전자에 돌연변이를 갖 고 있었으며, 7균주(10.8\%)가 parE유전자에 돌연변이를 포함 하고 있었다. 35 균주는 $g y r A$ 와 $\operatorname{parC}$ 유전자에 모두 돌연변이 를 가지고 있는 것으로 나타났다. 총 65균주의 대장균을 대상으 로 plasmid-mediated quinolone resistance (PMQR) determinants를 조사하였다. 65균주의 nalidixic acid 내성 대 장균중 13 균주에서 $q n r S$ 유전자가 검출되었으나 이 중 10 균주 는 gyrA, parC, parE 유전자에 돌연변이를 포함하고 있는 것을 나타났다. 본 연구에서는 사람과 돼지로부터 분리된 대장균이 quinolone 계열 항균제에 내성을 나타내는데 중요한 역할을 하 는 기전이 gyrA, parC, parE유전자에 염색체 돌연변이가 발생 하는 경우임을 확인하였는데 이 돌연변이들은 치료목적 또는 동물의 성장촉진을 위한 항균제의 과다사용으로 유발될 수 있다.

Acknowledgements: This work was supported by the 2018 Far East University Research Grant (FEU2018R20). Conflict of interest: None

Author's information (Position): Sung JY, Professor.

\section{REFERENCES}

1. Hooper DC. Mechanisms of action and resistance of older and newer fluoroquinolones. Clin Infect Dis. 2000;31:S24-S28.

2. EMA. Sales of veterinary antimicrobial agents in 19 EU/EEA countries in 2010. Second ESVAC report. London; European medicines agency; 2012.

3. van den Bogaard AE, Stobberingh EE. Antibiotic usage in animals: impact on bacterial resistance and public health. Drugs. 1999;58:589-607.

4. Chae SM, Park EJ, Park S. Antibiotic consumption and ex- penditures for acute upper respiratory tract infections in outpatients. Yakhak Hoeji. 2013;57:199-204. https://doi.org/10.2807/1560-7917.ES.2016.21.26.30266.

5. Paltansing S, Kraakman ME, Ras JM, Wessels E, Bernards AT. Characterization of fluoroquinolone and cephalosporin resistance mechanisms in Enterobacteriaceae isolated in a Dutch teaching hospital reveals the presence of an Escherichia coli ST131 clone with a specific mutation in parE. J Antimicrob Chemother. 2013;68:40-45. https://doi.org/10.1093/jac/dks365.

6. Hooper DC, Jacoby GA. Topoisomerase inhibitors: fluoroquinolone mechanisms of action and resistance. Cold Spring Harb Perspect Med. 2016;6:a025320. https://doi.org/10.1101/ cshperspect.a025320.

7. Cattoir V, Poirel L, Rotimi V, Soussy CJ, Nordmann P. Multiplex PCR for detection of plasmid-mediated quinolone resistance qnrgenes in ESBL-producing enterobacterial isolates. J Antimicrob Chemother. 2007;60: 394-397.

8. Park CH, Robicsek A, Jacoby GA, Sahm D, Hooper DC. Prevalence in the United States of aac $\left(6^{\prime}\right)-I b-c r$ encoding a ciprofloxacin-modifying enzyme. Antimicrob Agents Chemother. 2006;50(11):3953-3955.

9. Majlesi A, Kakhki RK, Mozaffari Nejad AS, Mashouf RY, Roointan A, Abazari M, et al. Detection of plasmid-mediated quinolone resistance in clinical isolates of Enterobacteriaceae strains in Hamadan, West of Iran. Saudi J Biol Sci. 2018;25: 426-430. https://doi.org/10.1016/j.sjbs.2016.11.019.

10. Doi Y, Park YS, Rivera JI, Adams-Haduch JM, Hingwe A, Sordillo EM, et al. Community-associated extended-spectrum $\beta$-lactamase-producing Escherichia coli infection in the United States. Clin Infect Dis. 2013;56:641-648. https://doi.org/ 10.1093/cid/cis942.

11. CLSI. Performance standards for antimicrobial susceptibility testing; sixteenth informational supplement. CLSI document M100-S20. Wayne, Pennsylvania: Clinical and Laboratory Standards Institute; 2010. p52-53.

12. Aoike N, Saga T, Sakata R, Yoshizumi A, Kimura S, Iwata M, et al. Molecular characterization of extraintestinal Escherichia coli isolates in Japan: relationship between sequence types and mutation patterns of quinolone resistance-determining regions analyzed by pyrosequencing. J Clin Microbiol. 2013;51:16921698. https://doi.org/10.1128/JCM.03049-12.

13. Xia LN, Li L, Wu CM, Liu YQ, Tao XQ, Dai L, et al. A survey of plasmid-mediated fluoroquinolone resistance genes from Escherichia coli isolates and their dissemination in Shandong, China. Foodborne Pathog Dis. 2010;7:207-215. https://doi.org/10.1089/fpd.2009.0378.

14. Kim HB, Wang M, Park CH, Kim EC, Jacoby GA, Hooper DC. oqxAB encoding a multidrug efflux pump in human clinical isolates of 13 Enterobacteriaceae. Antimicrob Agents Chemother. 2009;53:3582-3584. https://doi.org/10.1128/AAC.01574-08.

15. Zhao L, Zhang J, Zheng B, Wei Z, Shen P, Li S, et al. Molecular epidemiology and genetic diversity of fluoroquinolone-resistant Escherichia coli isolates from patients with community-onset infections in 30 Chinese county hospitals. J Clin Microbiol. 2015;53:766-770. https://doi.org/10.1128/JCM. 02594-14.

16. Hu YS, Shin S, Park YH, Park KT. Prevalence and mechanism of 
fluoroquinolone resistance in Escherichia coli isolated from swine feces in Korea. J Food Prot. 2017;80:1145-1151. https://doi.org/10.4315/0362-028X.JFP-16-502.

17. Paltansing S, Kraakman ME, Ras JM, Wessels E, Bernards AT. Characterization of fluoroquinolone and cephalosporin resistance mechanisms in Enterobacteriaceae isolated in a Dutch teaching hospital reveals the presence of an Escherichia coli ST131 clone with a specific mutation in parE. J Antimicrob Chemother. 2013;68:40-45. https://doi.org/10.1093/jac/dks365.

18. Yeh JC, Lo DY, Chang SK, Chou CC, Kuo HC. Prevalence of plasmid-mediated quinolone resistance in Escherichia coli isolated from diseased animals in Taiwan. J Vet Med Sci. 2017;79:730-735. https://doi.org/10.1292/jvms.16-0463.

19. Park JM, Choi SS. Molecular characterization of quinolone anti- biotic resistance in Escherichia coli isolated from retail meat in Seoul. Yakhak Hoeji. 2016;60:1-7. https://doi.org/10.1186/ s13620-017-0095-8.

20. Sung JY. The prevalence of plasmid-mediated quinolone resistance genes among CTX-M-14 producing Escherichia coli strains isolated from a university hospital in the Chungcheong province. Korean J Clin Lab Sci. 2016;48:210-216. https://doi.org/10.15324/kjcls.2016.48.3.210.

21. Yang HY, Nam YS, Lee HJ. Prevalence of plasmid-mediated quinolone resistance genes among ciprofloxacin-nonsusceptible Escherichia coli and Klebsiella pneumoniae isolated from blood cultures in Korea. Can J Infect Dis Med Microbiol. 2014;25: 163-169. 